\title{
Kesiapan Institusi Lokal dalam Menghadapi Bencana Tsunami: Studi Kasus Kelurahan Air Manis dan Kelurahan Purus, Kota Padang
}

\author{
Khoirul Anam ${ }^{1}$ \\ Magister Pengelolaan Terpadu Sumber Daya Alam \\ Universitas Andalas, Padang, Indonesia
}

\section{Abdul Mutholib}

Program Doktor IImu Pertanian, Universitas Andalas

Padang, Indonesia

\section{Febry Setiyawan}

Magister Pengelolaan Terpadu Sumber Daya Alam

Universitas Andalas, Padang, Indonesia

\section{Bevi Astika Andini}

Magister Pengelolaan Terpadu Sumber Daya Alam

Universitas Andalas, Padang, Indonesia

\section{Sefniwati}

Magister Pengelolaan Terpadu Sumber Daya Alam

Universitas Andalas, Padang, Indonesia

Artikel Masuk : 6 September 2017

Artikel Diterima : 5 Februari 2018

Tersedia Online : 29 April 2018

\begin{abstract}
Abstrak: Tsunami Aceh pada tahun 2004 telah memberikan dampak signifikan terhadap usaha penanggulangan bencana di Indonesia. Pergeseran paradigma penanggulangan bencana menuju penanggulangan bencana yang bersifat proactive preparedness menuntut keterlibatan berbagai pihak tidak terkecuali institusi lokal seperti kelurahan/desa. Kesiapan berbagai institusi di berbagai level dalam menghadapi bencana tsunami telah banyak dikaji termasuk kesiapan pemerintah lokal. Namun, kajian kesiapan pada tingkatan yang lebih rendah seperti institusi lokal (kelurahan/desa) belum banyak ditemukan, padahal kelurahan/desa merupakan institusi tingkat lokal yang bersentuhan langsung dengan masyarakat. Penelitian ini bertujuan memberikan gambaran kesiapan institusi lokal dalam menghadapi bencana tsunami dengan mengambil kasus di Kelurahan Air Manis dan Kelurahan Purus. Kedua kelurahan ini terletak di wilayah pesisir Kota Padang yang merupakan salah satu daerah dengan tingkat risiko tsunami yang tinggi. Penelitian ini menggunakan pendekatan kualitatif deskriptif, dengan menggunakan pengumpulan data
\end{abstract}

\footnotetext{
${ }^{1}$ Korespondensi Penulis: Magister Pengelolaan Terpadu Sumber Daya Alam, Universitas Andalas, Padang, Indonesia Email:manaanam96@gmail.com
} 


\title{
16 Kesiapan Institusi Lokaldalam Menghadapi Bencana Tsunami ...
}

primer berupa wawancara mendalam dengan informan kunci dan pengumpulan data sekunder berupa dokumen-dokumen yang terkait dengan penanggulangan bencana di Kota Padang. Kesiapan masyarakat di kedua wilayah dalam menghadapi bencana alam diidentifikasi melalui aspek fisik dan nonfisik yang berhubungan dengan pengurangan risiko bencana tsunami. Hasil penelitian menunjukkan bahwa secara fisik dan nonfisik Kelurahan Purus memiliki kesiapan yang lebih baik dibandingkan dengan Kelurahan Air Manis. Namun, dari sisi nonfisik TRANTIB-PB dan KSB sebagai representasi pelibatan institusi lokal dalam penanggulangan bencana masih perlu pembenahan tata kelola agar tidak menjadi sebuah formalitas belaka. Selain itu, kedua kelurahan tersebut merupakan destinasi wisata belum dipertimbangkan dalam manajemen bencana.

Kata kunci: bencana tsunami, kesiapan institusi lokal, pariwisata dan bencana

\begin{abstract}
Aceh Tsunami's in 2004 has a significant impact on Indonesia disaster management. Shifting of disaster management paradigm has directed to proactive preparedness that is involving some stakeholders including local institution like villages. At any level, the preparedness for the tsunami disaster of a government institution has been studied, including local government. However, in the lower level of local government such as villages have few of studies about that. Villages are institutions that deal directly with local communities. Therefore, the description of the preparedness/readiness of local institutions is needed. This study aims to give an overview of the readiness of local institutions in the face of the tsunami disaster by cases in the Air Manis Urban Village and Purus Village. Both of urban villages are located in the coastal area of Padang City which is one of the areas with high tsunami risk. This study uses descriptive qualitative approach, by using a primary data collection through in-depth interview with the key informant and secondary data collection through documents related to disaster management in Padang City. The local institution preparedness in both areas is identified through physical and non-physical aspects related to tsunami risk reduction. The results of the study showed that physically and non-physically Purus Village has better readiness compared to Air Manis Village. However, from the non-physical aspects of TRANTIB-PB and KSB as a representation of the involvement of local institutions in disaster management, it is still necessary to improve the governance in order not to become a mere formality. These two urban villages as a tourism destination are not considered in disaster management.
\end{abstract}

Keywords: local Institutions preparedness, tourism and disaster, tsunami disaster

\section{Pendahuluan}

Sebagai negara yang dikelilingi oleh jalur gunung berapi, Indonesia menjadi salah satu negara yang memiliki tingkat risiko tinggi terhadap bencana gempa dan tsunami. Kejadian bencana gempa bumi dan tsunami di Aceh pada tahun 2004 yang menelan 126.741 jiwa dan lebih dari 750.000 orang kehilangan mata pencaharian menunjukkan besarnya kerugian yang ditimbukan oleh bencana ini (BRR NAD-Nias, 2009). Kejadian bencana di Aceh telah menjadi dasar bagi perkembangan penanggulangan bencana di Indonesia. Dengan adanya Undang-Undang Nomor 24 Tahun 2007 tentang Penanggulangan Bencana dan Peraturan Presiden Nomor 8 Tahun 2008 tentang Badan Nasional Penanggulangan Bencana (BNPB), maka tanggung jawab penanggulangan bencana di Indonesia dikelola oleh institusi resmi BNPB. Kehadiran BNPB membuat perkembangan usaha penanggulangan bencana di Indonesia menemui titik terang agar dapat lebih terencana dan terarah (Chang Seng, 2013). Sistem otonomi daerah yang telah dijalankan sejak reformasi selanjutnya menuntut pembentukan lembaga khusus yang menangani kebencanaan di daerah, sehingga Badan Penanggulangan Bencana Daerah (BPBD) kemudian berangsur-angsur terbentuk di masing-masing daerah, sebagai turunan dari BNPB. 
Secara umum penanggulangan bencana terbagi menjadi tiga filosofi, pertama menjauhkan masyarakat dari ancaman bencana (hazard); kedua menjauhkan bencana dari masyarakat; apabila kedua sikap tersebut sulit untuk dilakukan maka pilihan selanjutnya adalah hidup harmoni dan bersahabat dengan ancaman serta mengembangkan kearifan lokal. Pemerintah mampu menggunakan ketiga filosofi ini dalam pengelolaan risiko bencana melalui program dan kebijakan untuk meminimalisasi dampak dari bencana (Maarif, 2012), termasuk dengan melibatkan masyarakat dan institusi lokal.

Selama ini ancaman dan bahaya dari bencana alam seringkali hanya dianggap sebagai proses alamiah lingkungan, sehingga masyarakat kurang dipertimbangkan dalam pengelolaan risiko bencana. Oleh karena itu, solusi-solusi yang bersifat teknis sering menjadi pilihan untuk menanggulangi risiko bencana, padahal tidak dapat dipungkiri bahwa solusi-solusi teknis tidak sepenuhnya mampu menyelesaikan masalah kebencanaan tersebut. Mempertimbangkan kondisi tersebut, maka pelibatan institusi lokal dan masyarakat yang rentan menjadi bagian dari solusi dan merupakan alternatif penyelesaian masalah kebencanaan. Dalam berbagai kesempatan, peran institusi lokal dan masyarakat dipertimbangkan sebagai komponen utama dalam mengatur masyarakat yang berada di daerah rawan bencana untuk berperan dalam penanggulangan bencana alam. Hal ini dilakukan dalam rangka mewujudkan kesiapsiagaan untuk menghadapi bencana. Mallick \& Vogt (2011) menyatakan bahwa manajemen bencana yang efektif membutuhkan kolaborasi antara negara, sektor swasta dan masyarakat sipil. Sejauh ini, pelibatan berbagai pihak dalam upaya penanggulangan bencana di Indonesia telah dilakukan namun efektivit as dan formulasinya masih perlu dikaji. Pada tingkat lokal, institusi lokal dalam hal ini institusi kelurahan memegang peranan penting dalam keberhasilan kolaborasi ketiga pihak tersebut.

Membangun kesiapan dalam menghadapi bencana merupakan salah satu hal penting dalam upaya penanggulangan bencana. Paradigma penanggulangan bencana telah mengalami pergeseran dari fatalistic responsive yang berorientasi pada respon kedaruratan akibat bencana menuju kepada proactive preparedness yaitu penanggulangan bencana yang dilakukan sejak dini melalui kesiapsiagaan hingga tahap pemulihan sosial. Paradigma ini menuntut pemerintah dan masyarakat secara bersama-sama melaksanakan upaya pengurangan risiko (Raja, Hendarmawan, \& Sunardi, 2017). Kesiapan (readiness/ preparedness) merupakan kesediaan untuk memberikan respon atau bereaksi, sehingga kesiapan menghadapi bencana diartikan sebagai kondisi sedia untuk memberikan respon dan tindakan yang mengarah pada peningkatan kapasitas dalam menanggapi suatu situasi bencana (Sopaheluwakan et al., 2006). Tindakan ini dapat dilakukan oleh berbagai pihak yang berkepentingan baik itu institusi pemerintah, swasta, masyarakat, individu maupun kerja sama di antara mereka. Bentuk kesiapan ini dapat terlihat secara fisik yang berupa ketersediaan sarana dan prasarana untuk penanggulangan bencana maupun nonfisik berupa peningkatan pengetahuan, sikap, perilaku, dan tata kelola lembaga dalam menghadapi bencana. Studi mengenai kesiapan dalam penanggulangan bencana di Indonesia difokuskan pada tiga pihak, yaitu rumah tangga, pemerintah dan komunitas sekolah (Sopaheluwakan et al., 2006). Secara garis besar, tanggung jawab utama dalam penanggulangan bencana berada di tangan pemerintah. Kesiapan pemerintah dalam penanggulangan bencana telah banyak digambarkan terutama pada level pemerintah pusat hingga kabupaten/kota serta kecamatan (Chang Seng, 2013; Hidayati, 2008; Madan \& Routray, 2015). Namun, kesiapan pada tingkat yang lebih kecil seperti desa/kelurahan belum terpetakan secara baik, padahal institusi kelurahan merupakan institusi yang paling banyak bersentuhan dengan masyarakat secara langsung. Studi mengenai hal tersebut perlu dilakukan jika ingin mencapai upaya penanggulangan bencana yang inklusif. Penelitian ini bertujuan untuk memberikan gambaran kesiapan institusi lokal yang merupakan struktur lokal dalam pemerintahan dalam menghadapi bencana tsunami dengan mengambil contoh kasus di dua kelurahan, yaitu Kelurahan Purus dan Kelurahan Air Manis, keduanya di Kota Padang. 
Sebagaimana diketahui, hampir separuh dari populasi dunia tinggal di kawasan pesisir, sehingga masyarakat di kawasan ini rentan terhadap bahaya dan risiko bencana pesisir seperti badai, abrasi, banjir rob dan tsunami (Stockholm International Water Institute, 2005), tidak terkecuali Kota Padang yang merupakan kota terbesar di pesisir barat Pulau Sumatera, juga tidak luput dari bencana tersebut. Menurut Natawidjaja (2005) dan Permana (2005), pesisir barat Pulau Sumatera merupakan salah satu wilayah yang paling rentan terhadap bahaya tsunami karena wilayah ini menghadap Samudera Hindia yang merupakan zona lempeng tektonik aktif dan rawan gempa. Pasca tsunami Aceh, Kota Padang berusaha menyiapkan diri menghadapi kemungkinan terjadinya bencana tsunami. Peningkatan kesiapan dalam menghadapi bencana tsunami di Kota Padang melibatkan berbagai pihak terkait, termasuk institusi lokal dalam hal ini kelurahan-kelurahan di Kota Padang. Peningkatan kesiapan dilakukan melalui upaya pengurangan risiko bencana tsunami yang mempertimbangkan aspek fisik, lingkungan, ekonomi dan sosial masyarakat.

\section{Metode Penelitian}

\section{Lokasi dan Waktu Penelitian}

Penelitian ini dilakukan di dua kelurahan yang terletak di Kota Padang, yaitu Kelurahan Purus dan Kelurahan Air Manis. Pemilihan lokasi ini dilakukan dengan mempertimbangkan lokasi kedua kelurahan yang terletak di wilayah pesisir dan merupakan destinasi wisata populer di Kota Padang.

\section{Pengumpulan dan Analisis Data}

Penelitian ini merupakan penelitian studi kasus dengan menggunakan teknik pengumpulan data berupa survei lapangan, wawancara mendalam terhadap informan kunci dan pengumpulan data sekunder yang berkaitan dengan penanggulangan bencana di Kelurahan Purus dan Kelurahan Air Manis. Survei lapangan dilakukan untuk melihat sarana dan prasarana penanggulangan bencana yang tersedia di lokasi penelitian, sedangkan wawancara mendalam dilakukan untuk mendapatkan gambaran sikap, kebijakan dan rencana institusi lokal dalam menghadapi bencana tsunami. Penentuan informan kunci dilakukan dengan menggunakan kombinasi purposive sampling dan snowball sampling. Jenis sampling ini dipilih karena penelitian ini membutuhkan informasi dan data yang akurat dari beberapa pemangku kepentingan yang terlibat dalam upaya penanggulangan risiko bencana. Wawancara dilakukan terhadap informan kunci yang meliputi Kepala BPBD Kota Padang, Lurah Air Manis dan Lurah Purus sedangkan dua informan kunci lainnya adalah Ketua Kelompok Siaga Bencana (KSB) di Kelurahan Purus dan Kelurahan Air Manis. Selanjutnya, data sekunder berupa buku, laporan, jurnal penelitian dan lain sebagainya dikumpulkan dari berbagai sumber baik yang didapatkan melalui instansi, seperti BPBD Kota Padang, Badan Pusat Statistik (BPS), kelurahan, maupun yang didapatkan melalui internet. Teknik analisis data yang digunakan adalah analisis kualitatif deskriptif dengan cara data-data yang telah dikumpulkan kemudian dikategorikan agar dapat ditafsirkan dan diinterpretasikan, dengan tujuan untuk menghasilkan gambaran yang sistematis, faktual dan akurat mengenai suatu fenomena. Gambar 1 menjelaskan kerangka analisis data.

Penulis menggambarkan kesiapan institusi lokal dalam menghadapi bencana tsunami di Kelurahan Purus dan Air Manis melalui identifikasi hal-hal yang terkait pengetahuan dan sikap terhadap bencana tsunami, kebijakan yang berhubungan dengan tsunami baik fisik maupun nonfisik, rencana tanggap darurat, sistem peringatan bencana tsunami dan kemampuan mobilisasi sumber daya yang tersedia baik sumber daya manusia (SDM) maupun pendanaan dan sarana (Sopaheluwakan et al., 2006) serta hal-hal yang terkait pengurangan risiko bencana. 


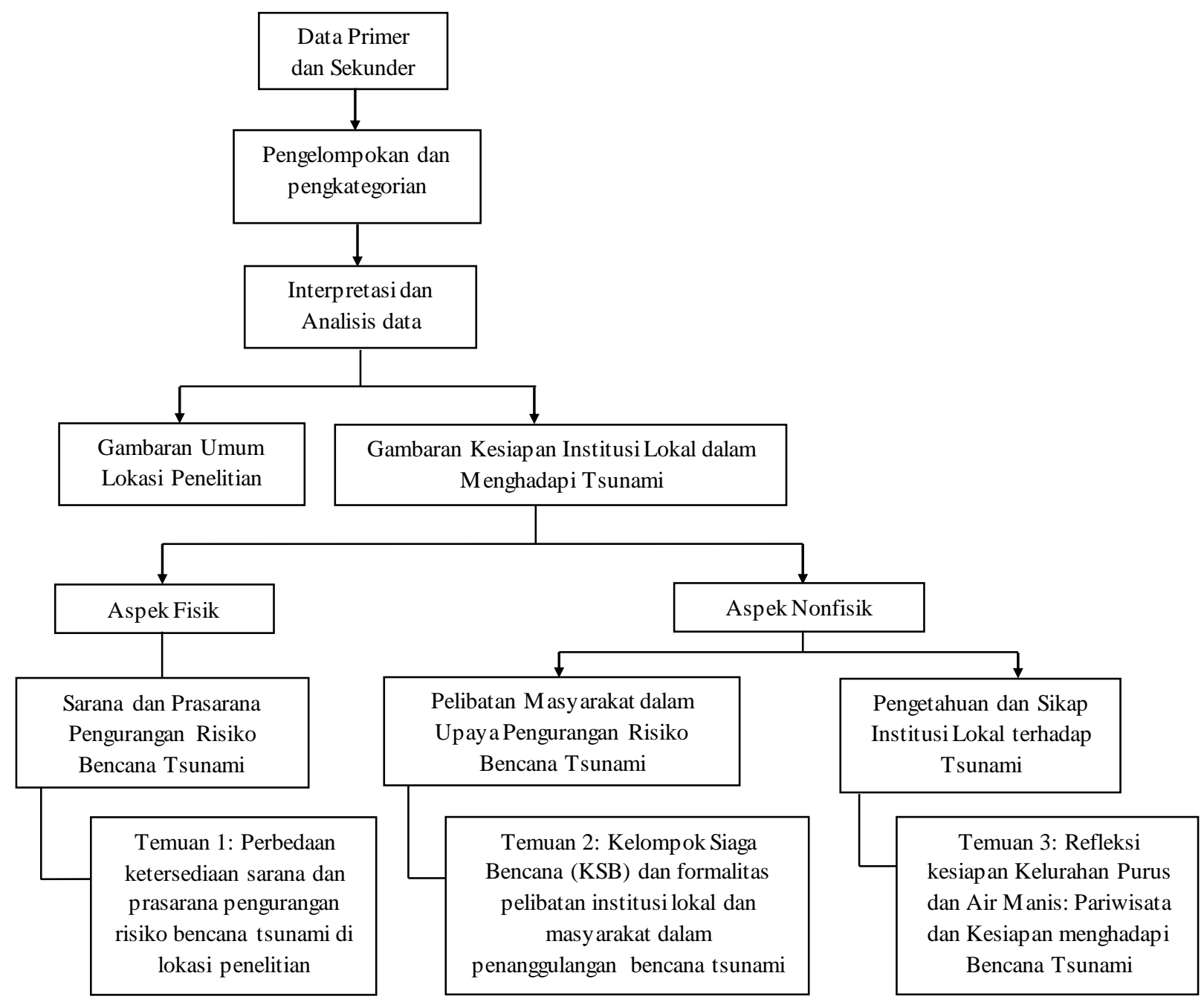

Gambar 1. Kerangka Analisis

\section{Hasil Pembahasan}

\section{Gambaran Umum dan Sejarah Kebencanaan di Lokasi Penelitian}

Kota Padang merupakan kota terbesar yang terletak di pesisir barat Pulau Sumatera. Secara geografis wilayah Kota Padang memiliki bentang alam yang bervariasi, mulai dari pulau-pulau kecil, kawasan pesisir dan perbukitan. Ketinggiannya bervariasi antara 0-1.853 $\mathrm{m}$ di atas permukaan laut dengan daerah tertinggi adalah Kecamatan Lubuk Kilangan. Kota Padang beriklim tropis dan memiliki curah hujan rata-rata mencapai $289,85 \mathrm{~mm}$ per bulan. Selain itu, Kota Padang berhadapan langsung dengan Samudera Hindia yang memiliki gelombang yang cukup besar dan lempeng tektonik aktif (BPS Kota Padang, 2016a; Pemerintah Kota Padang, 2013b).

Kota Padang terdiri atas 104 kelurahan, dari jumlah tersebut Kelurahan Purus dan Kelurahan Air Manis merupakan dua dari sekian banyak kelurahan yang terletak di wilayah pesisir Kota Padang. Kedua kelurahan ini berbatasan langsung dengan Samudera Hindia. Kelurahan Air Manis terletak lebih jauh dari pusat Kota Padang dibandingkan dengan Kelurahan Purus. Selain itu, bentang alam di Kelurahan Air Manis juga lebih bervariasi, sehingga akses menuju kelurahan ini jauh lebih sulit. Kawasan pantai di kedua kelurahan ini merupakan objek wisata utama di Kota Padang, yaitu Pantai Purus dan Pantai Air Manis. 
Luas wilayah Kelurahan Purus adalah 0,68 $\mathrm{km}^{2}$ dengan jumlah penduduk 7.888 jiwa (BPS Kota Padang, 2016b) berbanding terbalik dengan Kelurahan Air Manis yang luas wilayahnya hampir dua kali lebih luas dibandingkan wilayah Kelurahan Purus $\left(1,19 \mathrm{~km}^{2}\right)$, tetapi dengan jumlah penduduk yang lebih sedikit yaitu 1.509 jiwa (BPS Kota Padang, 2016c). Rasio jenis kelamin penduduk di Kelurahan Purus adalah 100,27 tidak berbeda jauh dengan Kelurahan Air Manis yaitu 102,27.

Berdasarkan kondisi geografis dan demografis Kota Padang terdapat tujuh jenis ancaman bahaya/bencana utama yang mengancam kota ini, yaitu gempa bumi, tsunami, badai/angin puting beliung, banjir dan banjir bandang, gelombang ekstrim dan abrasi pantai, tanah longsor, dan kebakaran. Berdasarkan tujuh jenis ancaman bencana alam tersebut, Kota Padang memiliki tingkat risiko bencana yang tinggi. Namun, sejak tahun 1815 hingga 2012, bencana banjir mendominasi kejadian di Kota Padang, disusul oleh gempa bumi, tanah longsor, gelombang ekstrem dan abrasi serta cuaca ekstrem. Meskipun jumlah kejadian gempa bumi lebih sedikit dibandingkan dengan kejadian banjir, namun dalam kurun waktu tersebut kejadian gempa bumi di Padang telah menyebabkan 774 orang meninggal dunia, 2.462 orang luka-luka dan 79.016 bangunan rusak berat. Angka ini jauh lebih besar dibandingkan total kerugian dari bencana lainnya (Pemerintah Kota Padang, 2013a). Selain itu, pada situasi dan kondisi tertentu gempa bumi memiliki efek samping an, yaitu timbulnya bencana tsunami. Berdasarkan Rencana Kontijensi Tsunami yang telah dibuat oleh Pemerintah Kota Padang pada tahun 2013, skenario terburuk dari kejadian gempa di Kota Padang adalah terjadinya gempa 8,8 SR akibat tumbukan (subduksi) antara Lempeng Samudera Hindia-Australia dan Lempeng Eurasia di bagian barat Pulau Mentawai. Gempa ini akan menghasilkan gelombang tsunami dengan ketinggian antara 8 12 meter (Pemerintah Kota Padang, 2013b).

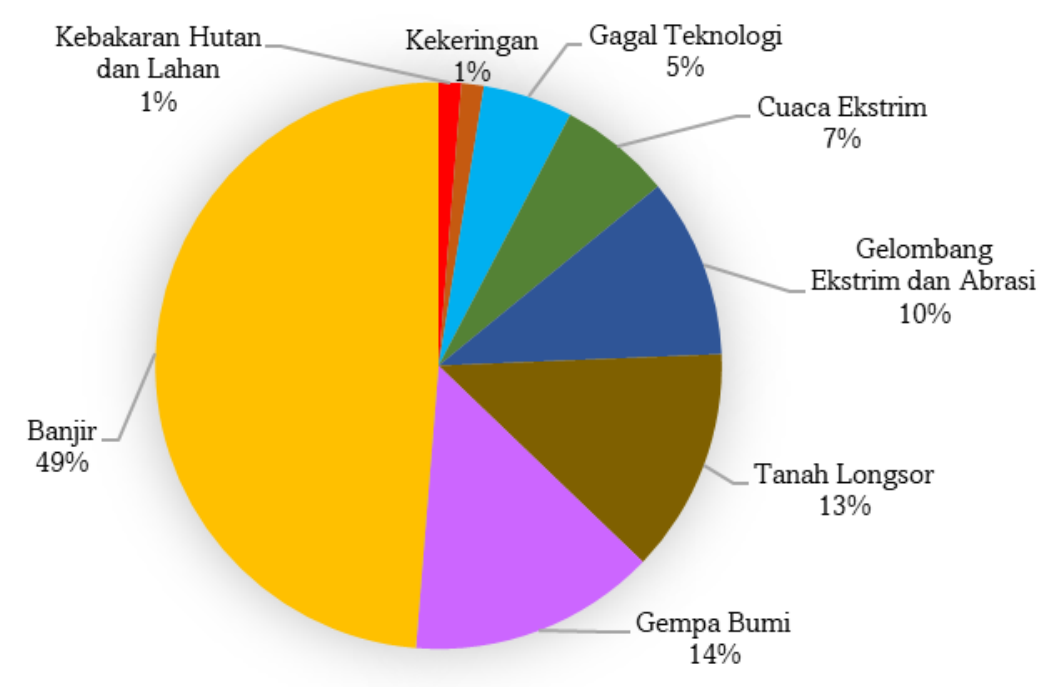

Sumber: Pemerintah Kota Padang, 2013a

\section{Gambar 2. Presentase Kejadian Bencana di Kota Padang}

Kelurahan Purus dan Kelurahan Air Manis yang letaknya di pesisir memiliki risiko bencana yang tinggi terhadap jenis bencana yang mengancam wilayah pesisir, seperti badai dan cuaca ekstrem, gelombang ekstrem dan abrasi pantai, banjir rob, terutama tsunami. Potensi kerugian dari keempat bencana pesisir ini mencapai Rp 164 milyar untuk Kelurahan Purus dan Rp 16 milyar untuk Kelurahan Air Manis, belum termasuk kerugian karena kehilangan jiwa. 
Tabel 1. Kondisi Kebencanaan di Kelurahan Purus dan Kelurahan Air Manis

\begin{tabular}{lcc}
\hline \multirow{2}{*}{ Jenis Bencana } & \multicolumn{2}{c}{ Risiko Bencana } \\
\cline { 2 - 3 } & Kelurahan Purus & Kelurahan Air Manis \\
\hline Badai dan cuaca ekstrim & Tinggi & Tinggi \\
Gelombang ekstrim dan abrasi & Tinggi & Tinggi \\
Tsunami & Tinggi & Tinggi \\
Banjir & Tinggi & Sedang \\
\hline
\end{tabular}

Sumber: Pemerintah Kota Padang, $2013 b$

\section{Kesiapan Kelurahan Purus dan Kelurahan Air Manis terhadap Bencana Tsunami}

Perkembangan paradigma penanggulangan bencana membuat peran institusi lokal terutama kelurahan semakin krusial. Kelurahan merupakan tingkatan terendah dari struktur pemerintahan daerah yang bertugas memberikan pelayanan kepada masyarakat. Tugas ini membuat kelurahan memiliki hubungan yang dekat dengan masyarakat. Dalam penanggulangan bencana, secara umum belum terdapat institusi yang khusus menangani penanggulangan bencana setingkat kelurahan. Di Kota Padang tanggung jawab penanggulangan bencana pada tingkat kelurahan termasuk ke dalam institusi kelurahan melalui Peraturan Wali Kota Padang Nomor 93 Tahun 2016, dengan tugas pokok dan fungsi penanggulangan bencana melekat pada Seksi Ketentraman, Ketertiban Umum dan Penanggulangan Bencana (TRANTIB dan PB). Hal ini merupakan langkah positif karena penanggulangan bencana merupakan upaya yang harus melibatkan berbagai pihak terkait di berbagai level termasuk pada level terendah.

\section{Gambaran Kesiapan terhadap Bencana Tsunami: Aspek Fisik}

Pasca gempa 2009, penyediaan sarana dan prasarana dalam rangka kesiapan menghadapi bencana di wilayah pesisir Kota Padang difokuskan pada ancaman bahaya tsunami. Hal ini dilakukan berdasarkan penilaian tingkat bahaya tsunami sebagai bencana paling berbahaya di Kota Padang (Pemerintah Kota Padang, 2013a). Kesiapan fisik dalam menghadapi bencana tsunami dapat dilihat dari ketersediaan peta jalur evakuasi, ketersediaan papan penanda jalur evakuasi, ketersediaan tempat evakuasi baik itu berupa Tempat Evakuasi Sementara (TES), Tempat Potensial Shelter (TPS) maupun shelter, ketersediaan papan informasi bencana tsunami, ketersediaan sistem peringatan dini serta sarana pendukung lain di kedua kelurahan tersebut.

Kelurahan Purus memiliki jumlah penduduk \pm 7 kali dari Kelurahan Air Manis (BPS Kota Padang, 2016c). Hal ini menjadi salah satu faktor pendukung untuk penyediaan sarana dan prasarana pengurangan risiko bencana tsunami yang lebih difokuskan di Kelurahan Purus, selain karena faktor geografisnya. Kelurahan Purus memiliki jalur evakuasi yang lebih banyak dibandingkan dengan Kelurahan Air Manis, hal ini dapat terlihat dari perbandingan jumlah jalan yang mengarahkan ke daerah yang lebih aman jika dilihat dari peta. Di lain sisi, Kelurahan Air Manis memiliki TES alami berupa perbukitan dengan ketinggian mencapai 300 mdpl. Perbukitan ini dapat ditempuh dengan waktu kurang dari 15 menit dari pinggir pantai. Walaupun demikian, hampir sebagian besar penduduk di kelurahan ini bermukim di wilayah yang berisiko tsunami. 


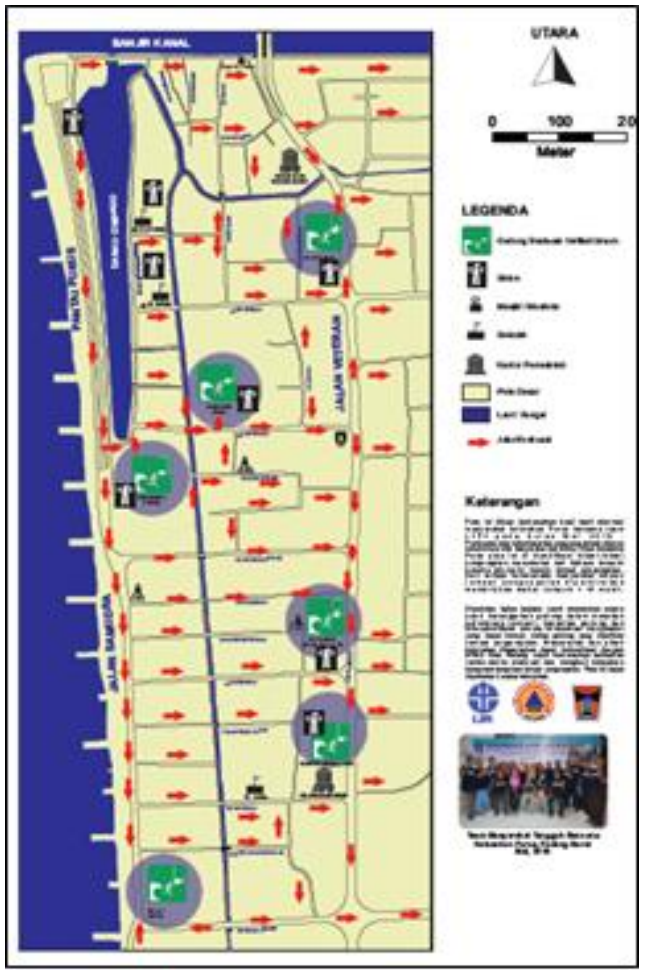

(a)

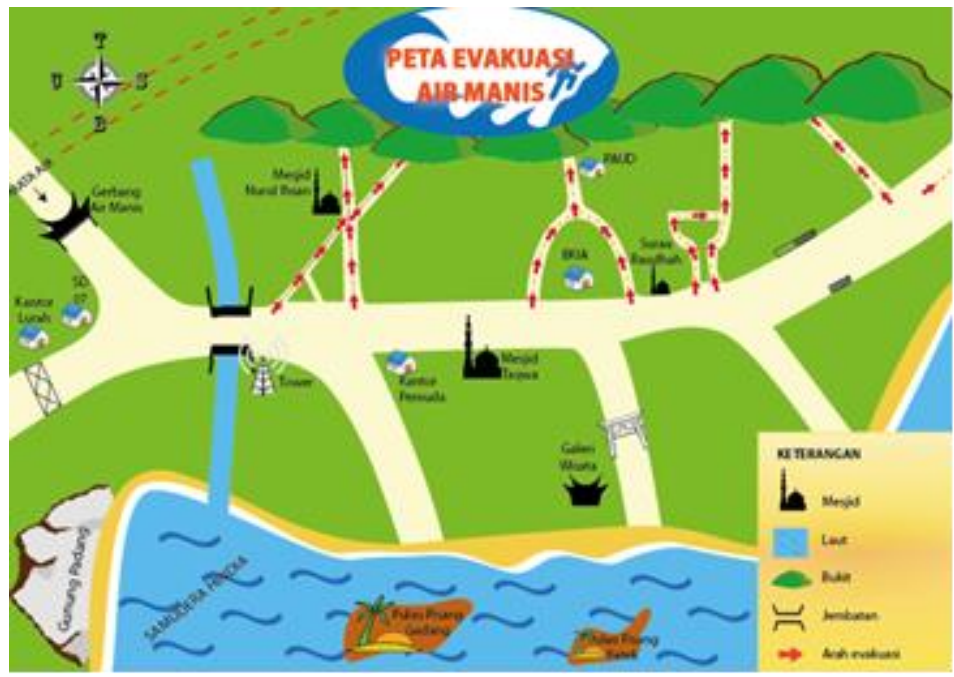

(b)

Sumber: BPBD Kota Padang, 2017

\section{Gambar 3. (a) Peta Jalur Evakuasi Kelurahan Purus; (b) Peta Jalur Evakuasi Kelurahan Air Manis}

Secara geografis Kelurahan Purus tidak diuntungkan jika dibandingkan dengan Kelurahan Air Manis, karena seluruh wilayah dari kelurahan ini berada pada ketinggian sekitar 5 mdpl. Selain itu, wilayah Kelurahan Purus merupakan wilayah perkotaan yang didominasi oleh permukiman dan bangunan-bangunan serta minim vegetasi (BPS Kota Padang, 2016b). Berdasarkan kondisi tersebut, tempat evakuasi berupa bangunan fisik baik TES maupun TPS cukup tersedia di Kelurahan Purus. Hal ini dijelaskan pada Peta Jalur Evakuasi Tsunami yang terdapat di Kelurahan Purus, terdapat 6 (enam) bangunan di Kelurahan Purus yang dapat menjadi tempat evakuasi sementara. Sementara itu, di 
Kelurahan Air Manis, keberadaan tempat evakuasi terhadap bencana tsunami berupa bangunan fisik belum teridentifikasi atau bahkan belum tersedia.

Peta jalur evakuasi tsunami di Kelurahan Purus cukup informatif dan dapat mudah dilihat oleh orang yang datang ke kantor kelurahan karena ditempel pada ruangan lobi. Peta tersebut merupakan hasil kerja sama antara oleh Pemerintah Kota Padang (termasuk Kelurahan Purus), LIPI dan BPBD Kota Padang. Hal ini berbanding terbalik dengan Kelurahan Air Manis yang belum memiliki peta jalur evakuasi yang informatif. Selain itu, sarana dan prasarana lain seperti rambu, peta dan papan penanda/informasi yang merupakan penyedia informasi kebencanaan telah tersedia di kedua kelurahan ini. Penyediaan informasi terkait kebencanaan merupakan amanat Undang Undang Nomor 24 tahun 2007 tentang Penanggulangan Bencana, Peraturan Pemerintah Nomor 21 tahun 2008 tentang Penyelenggaraan Penanggulangan Bencana dan Peraturan Pemerintah Nomor 25 tahun 2000 tentang Kewenangan Pemerintah dan Kewenangan Provinsi Sebagai Daerah Otonom. Kelurahan Purus juga lebih banyak memiliki sistem peringatan dini terhadap bahaya tsunami yang berupa sirene dibandingkan dengan Kelurahan Air Manis. Sirene ini tersebar di berbagai lokasi di wilayah Kelurahan Purus.

Struktur pemecah ombak di sepanjang pantai Kelurahan Purus juga turut membantu mengurangi kerentanan terhadap bencana tsunami. Kondisi ini tidak terjadi di Kelurahan Air Manis, karena di Pantai Air Manis belum memiliki struktur fisik pemecah ombak, akibatnya pada tahun 2016 sebelas rumah dan satu sekolah dasar di kelurahan ini terancam oleh abrasi pantai. Penyediaan sarana dan prasarana pengurangan risiko bencana merupakan salah satu aspek penting dalam penanggulangan bencana. Upaya ini termasuk ke dalam mitigasi bencana yang bersifat struktural (Sutton \& Tierney, 2006) dan merupakan bagian dalam strategi pembangunan kesiapan dalam menghadapi bencana tsunami (Intergovernmental Oceanographic Commission, 2008).

\section{Gambaran Kesiapan terhadap Bencana Tsunami: Aspek Nonfisik}

Kesiapan secara nonfisik Kelurahan Purus dan Kelurahan Air Manis dalam menghadapi bencana pesisir diidentifikasi dengan sejauhmana pengetahuan dan sikap institusi lokal dan masyarakat lokal terhadap bencana tsunami serta seberapa jauh institusi lokal dan masyarakat terlibat dalam upaya penanggulangan bencana pesisir. Pelibatan ini dapat berupa pelibatan pada tahap perencanaan maupun pelaksanaan program dan kebijakan penanggulangan bencana.

Tugas pokok, fungsi, serta struktur organisasi di kelurahan yang ada di Kota Padang dari tahun 2004 hingga tahun 2017 mengalami perubahan dengan memasukkan penanggulangan bencana menjadi salah satu tugas pokok dan fungsi seksi yang ada di kelurahan. Hal tersebut merupakan hal yang cukup berarti bagi pelibatan institusi dan masyarakat lokal dalam penanggulangan bencana. Selain itu, adanya tugas penanggulangan bencana yang dimasukkan ke dalam seksi di kelurahan menunjukkan sikap tanggap bencana dari institusi pemerintahan di Kota Padang sampai pada tingkat kelurahan.

Kelurahan Purus dan Kelurahan Air Manis telah memperoleh sosialisasi dan simulasi evakuasi bencana tsunami dari BPBD Kota Padang. Sosialisasi dan simulasi ini dilakukan sebanyak dua kali dalam setahun. Simulasi tsunami juga dilakukan oleh lembaga swadaya masyarakat (LSM) seperti Mercy Corps, dan Korps Siaga Tsunami (KOGAMI), seperti yang dilakukan di Kelurahan Air Manis. Pada setiap sosialisasi dan simulasi, institusi kelurahan bertindak sebagai mediator antara masyarakat dan pihak terkait lainnya.

Pada tahun 2016, Program Diseminasi dan Sosialisasi Bencana Tsunami diadakan di Kelurahan Purus dengan melibatkan institusi kelurahan dan masyarakat setempat. Program ini dibuat oleh Lembaga Ilmu Pengetahuan Indonesia (LIPI) yang bekerja sama dengan BPBD Kota Padang dan Kelurahan Purus. Salah satu hasil dari program ini adalah Peta Jalur Evakuasi Tsunami untuk wilayah Kelurahan Purus. Peta ini dapat ditemui di 


\section{Kesiapan Institusi Lokaldalam Menghadapi Bencana Tsunami ...}

Kantor Kelurahan Purus. Peta ini memperbarui peta yang sebelumnya dibuat oleh Mercy Corps.

Gambaran kesiapan secara nonfisik terhadap bencana tsunami juga terlihat dari respon masyarakat terhadap bencana yang lebih kecil tingkat bahayanya, seperti badai dan gelombang ekstrem. Di kedua kelurahan tersebut telah berkembang pengetahuan masyarakat lokal mengenai bencana. Pedagang yang berada di wilayah objek wisata Pantai Purus dan Pantai Air Manis mengetahui dengan baik mengenai badai dan gelombang ekstrem. Masyarakat mengetahui tanda-tanda kehadiran badai dan masa gelombang yang berada pada kondisi yang ekstrem. Selain itu, partisipasi mereka dalam menanggulangi ancaman abrasi juga terlihat dari kesediaan masyarakat Kelurahan Air Manis untuk bergotong-royong membuat tanggul sementara di daerah yang terkena abrasi.

Pengetahuan masyarakat lokal dalam melihat tanda-tanda bencana badai dan gelombang ekstrem, yang diwujudkan dengan sikap dan tindakan untuk mengevakuasi diri dari zona bahaya di kedua kelurahan tersebut, merupakan salah satu bentuk kesiapan masyarakat terhadap bencana. Untuk mewujudkan partisipasi dan pelibatan masyarakat dalam penanggulangan bencana di Kota Padang, Kelompok Siaga Bencana (KSB) dibentuk di masing-masing kelurahan. KSB dianggap sebagai wujud kerja sama antara institusi penanggulangan bencana (PEMDA, BNPB, BPBD, LIPI, NGO, LSM) dan institusi lokal.

\section{Kelompok Siaga Bencana (KSB) dan Formalitas Pelibatan Institusi Lokal dan Masyarakat dalam Penanggulangan Bencana Tsunami}

Pelibatan masyarakat sebagai kelompok rentan terhadap risiko bencana bukanlah hal baru. Pelibatan masyarakat dalam manajemen bencana mulai berkembang pada tahun 1970-an, terutama untuk meningkatkan kesadaran dan kesiapan dalam menghadapi bencana (Dekens, 2007). Dalam hubungan ini, pengetahuan lokal/kearifan lokal masyarakat secara perlahan mulai dimasukkan ke dalam manajemen bencana (McAdoo, Moore, \& Baumwoll, 2009). Perkembangan ini semakin terlihat setelah kejadian gempa yang disertai tsunami di Samudera Hindia pada tahun 2004, dengan komunitas yang mampu bertahan hidup dari bencana tersebut mulai menjadi objek kajian kebencanaan (Fritz \& Kalligeris, 2008).

Di Indonesia, pelibatan masyarakat dalam penanggulangan bencana pada tingkat kelurahan atau desa dilakukan dengan meluncurkan kebijakan dan program yang bertujuan untuk menghimpun pengetahuan lokal (kearifan lokal) mengenai kebencanaan serta meningkatkan kesiapan komunitas/masyarakat yang berada di daerah risiko bencana. Program Desa Tangguh Bencana (DESTANA) oleh Badan Nasional Penanggulangan Bencana (BNPB) dan Kampung Siaga Bencana oleh Kementerian Sosial merupakan suatu program yang dicetuskan sebagai bentuk pelibatan masyarakat lokal dalam penanggulangan risiko bencana.

Di Kota Padang, salah satu upaya pelibatan masyarakat lokal dalam manajemen bencana dilakukan melalui pembentukan organisasi berupa KSB di setiap kelurahan. Pembentukan ini diinisiasi oleh BPBD Kota Padang pada tahun 2011. Warga masyarakat yang telah diutus oleh masing-masing kelurahan diberikan pelatihan kesiapsiagaan bencana oleh BPBD dan kemudian dikukuhkan menjadi KSB di kelurahannya masing-masing. Fungsi utama KSB adalah sebagai kepanjangan tangan dari BPBD dalam memantau situasi kebencanaan di kelurahan. Masyarakat lokal dapat melaporkan potensi dan tanda-tanda bencana ke BPBD melalui KSB. KSB diharapkan mampu menjadi cikal-bakal masyarakat yang cerdas dalam menghadapi bencana.

Pelibatan KSB dalam kegiatan serta program penanggulangan bencana telah dilakukan sejak tahun pertama KSB dibentuk. Pada tahun 2011, melalui Program Keluarga Cerdas Bencana, BPBD Kota Padang melibatkan KSB yang ada di beberapa kelurahan untuk mengadakan sosialisasi dari pintu ke pintu mengenai bencana tsunami dan 
penanggulangannya. KSB Kelurahan Purus adalah salah satu yang dilibatkan dan sebanyak 750 keluarga mendapatkan sosialisasi mengenai bencana tsunami.

Saat ini KSB merupakan sebuah representasi pelibatan masyarakat dan institusi lokal dalam penanggulangan bencana di Kota Padang. Sebagian anggota KSB adalah tokohtokoh yang berpengaruh di masyarakat, termasuk tokoh adat dan alim ulama. Selama proses pembangunan, pelibatan tokoh masyarakat merupakan salah satu modal dalam keberhasilan pembangunan karena tokoh masyarakat memiliki kapasitas untuk mempengaruhi partisipasi masyarakat dalam pembangunan (Suhendi, 2013), termasuk dalam penanggulangan bencana.

Namun, kehadiran KSB yang diharapkan sebagai bentuk kolaborasi antara institusi kelurahan dan BPBD Kota Padang serta masyarakat belum mampu mencapai harapan, bahkan Ketua KSB di kedua lokasi penelitian sempat menganggap pembentukan KSB hanya sekedar formalitas belaka. Argumentasi ini bukan tanpa alasan, karena ketika pembentukan KSB belum disertai kejelasan alur koordinasi dan komunikasi antarpihak yang terkait, baik di Kelurahan Purus maupun Kelurahan Air Manis. Sementara itu, institusi kelurahan menempatkan diri hanya sebagai penghubung antara BPBD Kota Padang dan masyarakat lokal. Hal ini membuat KSB di beberapa kelurahan mulai tidak aktif, seperti yang terjadi di Kelurahan Air Manis. Pihak kelurahan akan menunjuk BPBD ketika ditanya mengenai siapa yang bertanggung jawab atas pembinaan KSB, sedangkan pihak BPBD mengaku memiliki keterbatasan anggaran dan personel BPBD Kota Padang untuk memberikan perhatian dan pembinaan secara kontinu kepada $104 \mathrm{KSB}$.

Pada awal tahun 2017, setelah sebelumnya melakukan perombakan struktur dan memberikan tambahan tugas dan fungsi penanggulangan bencana pada struktur organisasi di kelurahan (membentuk Seksi TRANTIB dan PB), Pemerintah Kota Padang mengeluarkan instruksi tentang pembentukan kembali/aktivasi KSB kelurahan dengan strategi yang berbeda. KSB yang secara formal tidak memiliki penanggung jawab kemudian 'dibentuk kembali' oleh kelurahan melalui penerbitan Surat Keputusan (SK) Lurah. Berdasarkan kondisi tersebut terlihat bahwa pembentukan KSB dan penerbitan SK Lurah dilakukan dalam rangka peningkatan fungsi kelurahan sebagai institusi lokal dalam usaha penanggulangan bencana di Kota Padang. Seksi TRANTIB dan PB di setiap kelurahan harus mampu memahami peran dan fungsinya secara utuh sebagai bagian dari institusi pemerintahan, karena Seksi TRANTIB dan PB merupakan ujung tombak bagi penanggulangan bencana. Seksi TRANTIB dan PB juga harus mampu mengajak pihakpihak terkait lainnya, terutama menghimpun peran swasta dan masyarakat melalui KSB dalam penanggulangan bencana termasuk membangun kesiapan dan mengurangi risiko bencana. Oleh karena itu, optimalisasi peran dan fungsi Seksi TRANTIB dan PB harus mulai dilakukan, terutama peningkatan kapasitas SDM dalam melakukan pembinaan dan respon terhadap bencana. Optimalisasi peran dan fungsi Seksi TRANTIB dan PB dimaksudkan agar terwujudnya penanggulangan bencana yang inklusif.

\section{Refleksi Kesiapan Kelurahan Purus dan Air Manis: Pariwisata dan Kesiapan Menghadapi Bencana Tsunami}

Beberapa dekade terakhir bencana alam telah mempengaruhi sektor pariwisata dunia. Sebagai contoh, tsunami yang terjadi di Samudera Hindia telah menyebabkan sektor pariwisata di Thailand mengalami resesi, dengan jumlah korban sebanyak 2.000 jiwa yang pada saat itu sedang berwisata di sekitar Phuket dan pesisir barat daya Laut Andaman (Henderson, 2007). Pariwisata dan bencana memiliki hubungan timbal-balik yang unik. Manusia berwisata karena ia ingin memperoleh kenyamanan dan menikmati hidup dengan terlepas sementara dari tekanan dan tuntutan pekerjaan. Oleh karena itu, destinasi wisata harus mampu menyediakan situasi dan keadaan yang terbebas dari krisis dan bencana (Zaenuri, 2016). Di sisi lain, beberapa destinasi wisata dengan bentang alam yang menarik merupakan tempat yang memiliki tingkat risiko bencana yang tinggi. Pada beberapa kasus, 
daerah rawan bencana sering dijadikan sebagai daya tarik wisata yang disebut sebagai disaster tourism.

Dalam perspektif kebencanaan, orang-orang yang berada di daerah bahaya bencana diperhitungkan sebagai bagian dari indeks kerentanan suatu daerah. Semakin tinggi kerentanan dalam menghadapi bencana, sementara kapasitasnya semakin rendah akan memperbesar risiko bencana (UNISDR, 2015). Saat ini sektor pariwisata menjadi salah satu andalan dalam meningkatkan perekonomian di Indonesia, khususnya di Provinsi Sumatera Barat termasuk di Kota Padang. Sebagai dua daerah destinasi wisata unggulan Kota Padang, Kelurahan Purus dan Kelurahan Air Manis merupakan titik berkumpulnya wisatawan dari berbagai daerah bahkan mancanegara. Pada saat yang bersamaan, kedua daerah tersebut juga merupakan daerah dengan tingkat bahaya tinggi terhadap bencana tsunami. Kehadiran wisatawan di Kelurahan Purus dan Kelurahan Air Manis secara tidak langsung menambah nilai kerentanan daerah tersebut, karena dalam kondisi biasa tanpa ancaman, wisatawan yang datang ke tempat wisata seringkali tidak terbiasa dengan lingkungan sekitar. Mereka terkendala oleh bahasa dan budaya yang kemungkinan besar akan membuat mereka kebingungan (Jeuring \& Becken, 2011), terutama dalam keadaan darurat bencana. Oleh karena itu, manajemen kebencanaan di daerah wisata harus mulai dibangun di Kota Padang, karena sebagian karakteristik dari industri pariwisata banyak bergantung pada lokasi-lokasi yang memiliki risiko bencana alam untuk melakukan berbagai aktivitasnya. Mempertimbangkan kondisi tersebut, perhatian terhadap manajemen bencana untuk pariwisata mulai berkembang (Becken \& Hughey, 2013).

Studi kasus yang dilakukan Becken \& Hughey (2013) di New Zealand dan Nortland memperlihatkan bahwa sektor kepariwisataan masih sedikit dipertimbangkan dalam kebijakan penanggulangan bencana. Hal tersebut juga ditemukan pada kebijakan dan program penanggulangan bencana di Kelurahan Purus dan Kelurahan Air Manis. Hasil wawancara dengan para informan kunci mengungkap temuan bahwa kehadiran wisataw an di kelurahan-kelurahan yang merupakan destinasi wisata hingga saat ini belum dipertimbangkan di dalam rencana strategis penanggulangan bencana di Kota Padang, padahal potensi kerugian akibat hilangnya jiwa cukup besar. Sebagai gambaran, pada Hari Raya Idul Fitri Tahun 2016, jumlah kunjungan wisatawan di Pantai Purus dan Pantai Muaro Lasak yang terletak di Kelurahan Purus dapat mencapai 50 ribu pengunjung dalam sehari (Ramadhan, 2016). Mempertimbangkan potensi kerugian jiwa tersebut, maka dibutuhkan rencana penanggulangan bencana pada daerah yang merupakan destinasi wisata di Kota Padang. Penanggulangan bencana pada daerah yang merupakan destinasi wisata membutuhkan kerja sama kolaboratif lintas-sektor, setidaknya dengan sektor pariwisata baik institusi pemerintah yang menangani pariwisata maupun pihak swasta yang bergerak pada industri pariwisata. Selain itu, masyarakat lokal yang telah menguasai lokasi sangat perlu untuk dilibatkan. Upaya kolaboratif dapat membuat sebuah konsep pemikiran penanggulangan bencana yang komprehensif, praktis dan transformatif.

Keterbatasan dalam memprediksi kejadian bencana sama sulitnya dalam menemukan formulasi yang tepat untuk kolaborasi pihak-pihak yang terkait. Upaya kolaboratif ini seringkali sulit diwujudkan karena aturan formal yang berbeda, normanorma informal, sumber daya yang berbeda yang kemudian mewujudkan ego sektoral. Faktor kunci keberhasilan kolaborasi adalah komunikasi. Kolaborasi membutuhkan aktor yang mampu menjadi komunikator yang terampil dan memainkan peran penting dalam membangun hubungan, memfasilitasi dan mengkoordinasikan kerja sama dan membangun jaringan yang kuat di antara pemangku kepentingan dengan berdasarkan kapasitas individu dan organisasi (Sullivan \& Skelcher, 2002). 


\section{Kesimpulan}

Paradigma penanggulangan bencana telah bergeser dari penanggulangan bencana yang bersifat responsif saat terjadi bencana menuju penanggulangan bencana yang bersifat kesiapan yang proaktif. Paradigma baru menuntut kesiapan pihak-pihak yang berkepentingan, termasuk institusi kelurahan/desa sebagai institusi lokal pada struktur pemerintahan. Kelurahan Purus dan Kelurahan Air Manis memiliki risiko yang tinggi terhadap bencana tsunami. Bencana tsunami yang merupakan bahaya sekunder dari gempa bumi menuntut kesiapan berbagai pihak termasuk institusi kelurahan.

Kesiapan institusi dalam menghadapi bencana tsunami diidentifikasi dari hal-hal yang mampu mengurangi risiko terhadap bahaya tsunami, yang dikelompokkan menjadi aspek fisik dan nonfisik. Dilihat dari aspek fisik, kesiapan tersebut berupa ketersediaan sarana dan prasarana penanggulangan bencana tsunami seperti TES, TPS, jalur evakuasi dan sarana informasi kebencanaan serta sarana pengurangan risiko bencana lainnya. Kesiapan Kelurahan Purus dalam penanggulangan bencana terlihat lebih baik daripada Kelurahan Air Manis. Berdasarkan aspek nonfisik, seperti pengetahuan dan sikap terhadap bencana tsunami, kebijakan terhadap bencana tsunami, kedua kelurahan telah memperoleh sosialisasi dan simulasi penanggulangan bencana tsunami, namun frekuensi dan kontinuitasnya perlu dijaga. Dilihat dari aspek kebijakan, kehadiran seksi yang menangani masalah penanggulangan pada struktur kelurahan yang ada di Kota Padang termasuk Kelurahan Purus dan Kelurahan Air Manis merupakan wujud dari sikap tanggap bencana dari institusi kelurahan. Optimalisasi seksi tersebut perlu dilakukan guna mewujudkan penanggulangan bencana yang inklusif. Selain itu, kehadiran KSB sebagai representasi pelibatan masyarakat merupakan langkah yang tepat dengan catatan bahwa kehadirannya bukanlah sekedar formalitas belaka. Oleh karena itu, institusi lokal dan pihak terkait harus merumuskan rencana strategis dalam pembinaan KSB.

Selain itu, dilihat dari kasus di kedua kelurahan tersebut, dapat disimpulkan bahwa manajemen bencana di Kota Padang belum mempertimbangkan kehadiran wisatawan pada daerah dengan risiko bencana tsunami yang tinggi sebagai faktor yang menambah kerentanan daerah tersebut. Kebijakan terkait hal ini belum ada baik di tingkat kota terlebih pada tingkat institusi lokal seperti kelurahan. Kelurahan Purus dan Kelurahan Air Manis sebagai destinasi wisata utama di Kota Padang dengan jumlah kunjungan wisata yang cukup besar terutama pada akhir pekan perlu mempersiapkan diri untuk mengurangi risiko bencana. Dilihat dari kondisi tersebut maka kesiapan institusi dan masyarakat lokal dari kedua kelurahan masih belum memadai. Penanggulangan bencana harus memperhatikan karakteristik setiap daerah melalui formulasi strategi, kebijakan serta program dan upaya kolaboratif yang melibatkan seluruh pemangku kepentingan.

\section{Daftar Pustaka}

Badan Penanggulangan Bencana Daerah (BPBD) Kota Padang. (2017). Peta jalur evakuasi Kelurahan Purus dan Air Manis. Padang: Badan Penanggulangan Bencana Daerah Kota Padang.

Badan Pusat Statistik (BPS) Kota Padang. (2016a). Kota Padang dalam angka 2016. Padang: Badan Pusat Statistik Kota Padang.

Badan Pusat Statistik (BPS) Kota Padang. (2016b). Statistik daerah Kecamatan Padang Barat 2016. Padang: Badan Pusat Statistik Kota Padang.

Badan Pusat Statistik (BPS) Kota Padang. (2016c). Statistik daerah Kecamatan Padang Selatan 2016. Padang: Badan Pusat Statistik Kota Padang.

Badan Rehabilitasi dan Rekonstruksi Aceh-Nias (BRR NAD-Nias). (2009). Laporan akhir Dewan Pengarah Badan Rehabilitasi dan Rekonstruksi Wilayah dan Kehidupan Masyarakat Provinsi Nanggroe Aceh dan Kepulauan Nias Provinsi Sumatera Utara, tahun 2005-2009. Aceh \& Nias: Dewan Pengarah BRR NAD- 


\section{Kesiapan Institusi Lokaldalam Menghadapi Bencana Tsunami...}

Nias.

Becken, S., \& Hughey, K. F. D. (2013). Linking tourism into emergency management structures to enhance disaster risk reduction. TourismManagement, 36, 77-85. doi:10.1016/j.tourman.2012.11.006.

Chang Seng, D. S. (2013). Tsunami resilience: Multi-level institutional arrangements, architectures and system of governance for disaster risk preparedness in Indonesia. Environmental Science and Policy, 29, 57-70. doi:10.1016/j.envsci.2012.12.009.

Dekens, J. (2007). Local knowledge for disaster preparedness: A literature Review. Nepal. Retrieved from http://www.preventionweb.net/files/2693_icimod8fc84ee621cad6e77e083486ba6f9cdb.pdf.

Fritz, H. M., \& Kalligeris, N. (2008). Ancestral heritage saves tribes during 1 April 2007 Solomon Islands tsunami. Geophysical Research Letters, 35(1), 1-5. doi:10.1029/2007GL031654.

Henderson, J. C. (2007). Corporate social responsibility and tourism: Hotel companies in Phuket, Thailand, after the Indian Ocean tsunami. International Journal of Hospitality Management, 26(1), 228-239. doi:10.1016/j.ijhm.2006.02.001.

Hidayati, D. (2008). Kesiapsiagaan masyarakat: Paradigma baru pengelolaan bencana alamdi Indonesia. Jurnal $\begin{array}{lllll}\text { Kependudukan } \quad \text { Indonesia, } & \text { 3(1), 69-84. } & \text { Retrieved }\end{array}$ http:// ejurnal.kependudukan.lipi.go.id/index.php/jki/article/view/164.

Intergovernmental Oceanographic Commission. (2008). Tsunami preparedness-Information guide for disaster planners (IOC Manuals and Guides No.49).

Jeuring, J., \& Becken, S. (2011). Who is protecting tourists in New Zealand from severe weather hazards? An exploration of the role of locus of responsibility in protective behaviour decisions. In Advancing the Social Science of Tourism 2011 (pp. 193-202). United Kingdom: University of Surrey.

Maarif, S. (2012). Merapi menyapa kehidupan hidup harmonis di Lereng Merapi. Jakarta: Badan Nasional Penanggulangan Bencana.

Madan, A., \& Routray, J. K. (2015). Institutional framework for preparedness and response of disaster management institutions from national to local level in India with focus on Delhi. International Journal of Disaster Risk Reduction, 14, 545-555. doi:10.1016/j.ijdrr.2015.10.004.

Mallick, B., \& Vogt, J. (2011). Social supremacy and its role in local level disaster mitigation planning in Bangladesh. Disaster Prevention and Management: An International Journal, 20(5), 543-556. doi:10.1108/09653561111178970.

McAdoo, B. G., Moore, A., \& Baumwoll, J. (2009). Indigenous knowledge and the near field population response during the 2007 Solomon Islands tsunami. Natural Hazards, 48(1), 73-82. doi:10.1007/s11069-008-9249$\mathrm{z}$.

Natawidjaja, D. H. (2005). Aceh-Gempa Andaman 28 Desember 2004. Paper dipresentasikan pada Pertemuan di BAPPENAS. Jakarta: Badan Perencanaan dan Pembangunan Nasional.

Pemerintah Kota Padang. (2013a). Kajian risiko bencana Kota Padang, Sumatera Barat 2014-2018. Padang.

Pemerintah Kota Padang. (2013b). Rencana kontijensi tsunami Kota Padang. Padang.

Permana, H. (2005). Pembelajaran dari Aceh: Pemahaman bencana geologi. Dipresentasikan pada Pertemuan di BAPPENAS. Jakarta.

Raja, Z. D. G., Hendarmawan, \& Sunardi. (2017). Upaya pengurangan risiko dan kesiapsiagaan masyarakat terhadap ancaman bencana tanah longsor (Desa Ndito, Kecamatan Detusoko, Kabupaten Ende, Provin si Nusa Tenggara Timur). Jurnal Lingkungan dan Bencana Geologi, 8(2), 103-116. Retrieved from http://jlbg.geologi.esdm.go.id/index.php/jlbg.

Ramadhan, B. (2016). Kunjungan wisatawan ke Pantai Padang capai 50 ribu orang/hari. Retrieved August 23, 2017, from http://www.republika.co.id/berita/ramadhan/kabar-ramadhan/16/07/10/oa2x5d330kunjungan-wisatawan-ke-pantai-padang-capai-50-ribu-oranghari.

Sopaheluwakan, J., Hidayati, D., Permana, H., Pribadi, K., Ismail, F., Meyers, K., ... Argo, T. (2006). Kajian 
kesiapsiagaan masyarakat dalam mengantisipasi bencana gempa bumi \& tsunami. Bandung: Lembaga Ilmu Pengetahuan Indonesia. Retrieved from http://www.bukue.lipi.go.id/utama.cgi?lihatarsip\&jans001\&1273262299.

Stockholm International Water Institute. (2005). Making water a part of economic development: The economic benefits of improved water management and services. Stockholm International Water Institute (SIWI). Stockholm. Retrieved from http://hdl.handle.net/10535/5146.

Suhendi, A. (2013). Peranan tokoh masyarakat lokal dalam pembangunan kesejahteraan sosial. Informasi, 18(2), 105-116. Retrieved from puslit.kemsos.go.id/hasil-penelitian/245/peranan-tokoh-masyarakat-lokaldalam-pembangunan-kesejahteraan-sosial\#sthash.UmDCBzQV.dpbs.

Sullivan, H., \& Skelcher, C. (2002). Working across boundaries: Collaboration in public services (government beyond the centre). Basingstoke: Palgrave Macmillan.

Sutton, J., \& Tierney, K. (2006). Disaster preparedness: Concepts, guidance, and research. Colorado.

UNISDR. (2015). Sendai framework for disaster risk reduction 2015 - 2030. Third World Conference on Disaster Risk Reduction, Sendai, Japan, 14-18March 2015. Geneva. doi:A/CONF.224/CRP.1.

Zaenuri, M. (2016). Tata kelola pariwisata-bencana dalamperpektif collaborative governance studipariwisata bencana volcano tour merapi di Kabupaten Sleman. Disampaikan pada Seminar Hasil Penelitian Dosen Jurusan Ilmu Pemerintahan FISIPOL UMY. Universitas Muhammadiyah Yogyakarta, Yogyakarta. Retrieved from http://repository.umy.ac.id/bitstream/handle/123456789/6446/PAPER SEMINAR HASIL PENELITIAN_zaenuri.pdf?sequence $=1$. 